\title{
IMPLEMENTASI METODE REGRESI LINIER SEDERHANA PADA PENYAJIAN HASIL PREDIKSI PEMAKAIAN AIR BERSIH PDAM WAY RILAU KOTA BANDAR LAMPUNG DENGAN SISTEM INFORMASI GEOFRAFIS
}

\author{
Astria Hijriani ${ }^{1)}$, Kurnia Muludi ${ }^{2)}$, Erlina Ain Andini ${ }^{3)}$ \\ 1, 2, 3) Jurusan Ilmu Komputer, FMIPA, Universitas Lampung \\ Jln. Soemantri Brojonegoro, Bandar Lampung \\ E-Mail : astria.hijriani@gmail.com ${ }^{1)}$; kmuludi@yahoo.com ${ }^{2)}$; erlina_ain@yahoo.com ${ }^{3)}$
}

\begin{abstract}
ABSTRAK
Banyaknya pelanggan dan pemakaian air bersih di suatu daerah yang masuk dalam zona pelayanan PDAM Way Rilau Kota Bandar Lampung diamati sebagai informasi yang dapat digunakan dalam perencanaan produksi air bersih di masa mendatang. Hasil prediksi jumlah pelanggan dan jumlah pemakaian air bersih akan bermanfaat dalam perencanaan produksi air bersih dan peningkatan layanan kepada pelanggan. Prediksi dapat dilakukan dengan berbagai metode, salah satunya metode regresi linier sederhana. Penelitian ini dilakukan dengan tujuan untuk membangun sistem informasi geografis yang dapat menyajikan hasil prediksi pemakaian air bersih kota Bandar Lampung dalam wilayah pelayanan PDAM Way Rilau Kota Bandar Lampung. Data pada penelitian ini diperoleh dari PDAM Way Rilau Kota Bandar Lampung. Hasil keseluruhan pengujian menunjukkan bahwa sistem informasi geografis penyebaran dan prediksi jumlah penduduk telah sesuai baik dari segi fungsionalitasnya, maupun dari segi interaksi sistem dengan pengguna.
\end{abstract}

Kata Kunci : sistem informasi geografis, regresi linier sederhana, pemetaan jumlah pemakaian air bersih

\section{PENDAhuluan}

Banyaknya pelanggan dan pemakaian air bersih di suatu daerah yang masuk dalam zona pelayanan PDAM Way Rilau Kota Bandar Lampung diamati sebagai informasi yang dapat digunakan dalam perencanaan produksi air bersih di masa mendatang. Hasil prediksi jumlah pelanggan dan jumlah pemakaian air bersih akan bermanfaat dalam perencanaan produksi air bersih dan peningkatan layanan kepada pelanggan. Memprediksi pemakaian air bersih dapat dilakukan dengan beberapa metode, salah satunya adalah metode regresi linier sederhana.

Penelitian sebelumnya, Bangun [1] telah memprediksi kebutuhan air bersih di kota Madiun berdasarkan jumlah penduduk yang dihitung menggunakan metode aritmatika, geometri, dan regresi linier sederhana. Hasil prediksi tersebut disajikan dalam tabel. Penelitian menggunakan regresi linier sederhana juga dilakukan oleh Syafruddin, dkk. [2] yang menghitung jumlah penduduk menggunakan regresi linier sederhana dan disajikan dalam bentuk tabel. Kedua penelitian tersebut menyajikan hasil prediksi dalam bentuk tabel, maka dari itu perlu dilakukan pengembangan terhadap proses dan penyajiannya seperti menggunakan sistem informasi geografis.

Penyajian dalam bentuk peta akan membantu proses pengamatan banyaknya pemakaian air bersih di suatu daerah. Sistem Informasi Geografis (SIG) adalah sebuah sistem yang dirancang untuk menangkap, menyimpan, memanipulasi, menganalisa, mengatur, dan menampilkan seluruh jenis data geografi [3].

Informasi mengenai hasil prediksi pemakaian air bersih sebaiknya disajikan dengan format yang baik agar mudah dipahami. Penyampaian informasi dapat dilakukan menggunakan berbagai media, salah satunya melalui peta yang ditampilkan dalam sistem informasi geografis. Sistem informasi geografis telah menjadi alat penting dalam menganalisis serta menyajikan data dan peta yang dapat digunakan dalam perencanaan yang terkait dimensi ruang dan waktu sehingga penggunaan sistem informasi geografis dapat membantu dalam penyajian informasi prediksi pemakaian air bersih di masa mendatang. Hal tersebut mendorong penulis untuk membuat suatu sistem informasi geografis yang diharapkan dapat memetakan prediksi pemakaian air bersih di kota Bandar Lampung. Sistem ini diharapkan mampu mempermudah penyampaian informasi mengenai banyaknya pemakaian air bersih di wilayah Bandar Lampung yang masuk dalam zona pelayanan PDAM Way Rilau Kota Bandar Lampung dan dapat menampilkan prediksi perubahan distribusi jumlah penduduk di wilayah Bandar Lampung. Manfaat dari sistem ini adalah untuk memberikan informasi mengenai prediksi jumlah pemakaian air bersih di Bandar Lampung dalam zona pelayanan air bersih PDAM Way Rilau Kota Bandar Lampung dan membantu PDAM dalam persiapan penyediaan kebutuhan air bersih di masa mendatang. 


\section{TINJAUAN PUSTAKA}

\section{a. Regresi Linier Sederhana}

Analisis regresi adalah suatu metode statistik yang mengamati hubungan antara variabel terikat $\mathrm{Y}$ dan serangkaian variabel bebas $\mathrm{X} 1, \ldots, \mathrm{Xp}$. Tujuan dari metode ini adalah untuk memprediksi nilai $\mathrm{Y}$ untuk nilai $\mathrm{X}$ yang diberikan. Model regresi linier sederhana adalah model regresi yang paling sederhana yang hanya memiliki satu variabel bebas $\mathrm{X}$. Analisis regresi memiliki beberapa kegunaan, salah satunya untuk melakukan prediksi terhadap variabel terikat Y [4]. Persamaan untuk model regresi linier sederhana adalah sebagai berikut.

$Y=a+b X$

$\mathrm{Y}$ adalah variabel terikat yang diramalkan, $\mathrm{X}$ adalah variabel bebas, a adalah intercep, yaitu nilai $\mathrm{Y}$ pada saat $\mathrm{X}=0$, dan $\mathrm{b}$ adalah slope, yaitu perubahan rata-rata $\mathrm{Y}$ terhadap perubahan satu unit $X$. Koefisien a dan $b$ adalah koefisien regresi dimana nilai $a$ dan $b$ dapat dicari menggunakan persamaan berikut.

$$
\begin{aligned}
& b=\frac{n(\Sigma x y)-(\Sigma x)(\Sigma y)}{n\left(\Sigma x^{2}\right)-(\Sigma x)^{2}} \\
& a=\frac{\Sigma y-b(\Sigma x)}{n}
\end{aligned}
$$

Nilai a adalah slope, $\mathrm{b}$ adalah intercep dan $\mathrm{n}$ adalah banyaknya data yang digunakan dalam perhitungan.

\section{b. Sistem Informasi Geografis}

Sistem Informasi Geografis (SIG) adalah sebuah sistem yang dirancang untuk menangkap, menyimpan, memanipulasi, menganalisa, mengatur, dan menampilkan seluruh jenis data geografi. SIG tidak lepas dari data spasial, yang merupakan sebuah data yang mengacu pada posisi, obyek, dan hubungan di antaranya dalam ruang bumi. Data spasial dalam SIG terbagi menjadi dua model data yaitu model data vektor dan model data raster. Model data vektor merepresentasikan bumi sebagai suatu mosaik yang terdiri atas garis (arc/line), polygon (daerah yang dibatasi oleh garis yang berawal dan berhenti pada titik yang sama), titik/point (node yang mempunyai label), dan nodes (merupakan titik perpotongan antara dua buah garis).

Model data raster atau sel grid merepresentasikan obyek geografis sebagai struktur sel grid yang diwakili oleh setiap pixel pada citra. Model data raster sangat baik untuk merepresentasikan batas-batas yang berubah secara gradual seperti jenis tanah, vegetasi, dan lain-lain [3].

\section{c. Metode Waterfall}

Pembangunan sistem ini menggunakan metode waterfall yang merupakan salah satu model pengembangan perangkat lunak yang umum digunakan. Model ini merupakan salah satu model yang sederhana yang memiliki tahap pengembangan perangkat lunak yang berbeda secara sekuensial. Model ini cocok digunakan untuk proyek berskala kecil [5]. Proyek skala kecil dikerjakan oleh kurang dari tiga orang selama kurang dari enam bulan [6].

\section{METODE PENELITIAN}

Diagram alir dari penelitian ini dcitunjukkan pada gambar 1 .

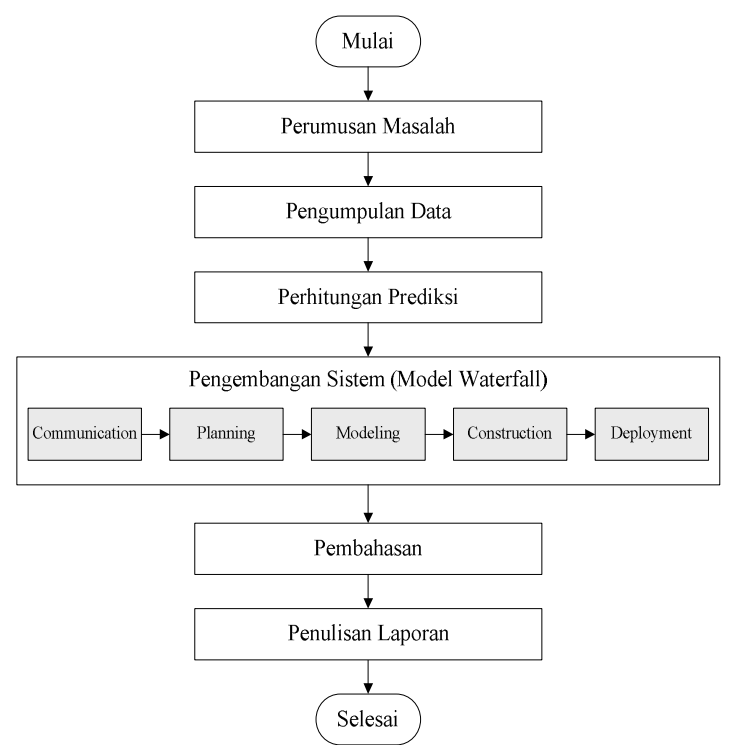

Gambar 1 Diagram Alir Penelitian

\section{a. Perumusan Masalah}

Perumusan masalah merupakan langkah awal yang dilakukan untuk mengidentifikasi dan menganalisis permasalahan yang ada. Pada langkah ini akan menghasilkan rumusan masalah, batasan masalah, tujuan penelitian, dan juga manfaaat penelitian.

\section{b. Pengumpulan Data}

Pegumpulan data pada penelitian ini dilakukan menggunakan metode studi literatur yang didapat dari dokumen, buku, atau jurnal mengenai penelitian sejenis. Studi literatur mengenai data jumlah pemakaian air bersih dan jumlah pelanggan diperoleh dari PDAM Way Rilau Kota Bandar Lampung.

\section{c. Perhitungan Prediksi}

Prediksi pemakaian air bersih pada penelitian ini akan dilakukan menggunakan metode regresi linier sederhana. 


\section{d. Analisa Kebutuhan Sistem}

Sebelum dilakukan perancangan dan pembangunan sistem, kebutuhan fungsional dan non fungsional sistem perlu diketahui agar sistem yang dibangun sesuai dengan kebutuhan pengguna. Adapun kebutuhan fungsional dari sistem informasi geografis prediksi pemakaian air bersih ini antara lain sebagai berikut.

- Sistem dapat menampilkan prediksi pemakaian air bersih PDAM Way Rilau Kota Bandar Lampung baik dalam bentuk tabel, peta, maupun grafik.

- Sistem dapat menampilkan data pertahun yang meliputi jumlah pelanggan dan pemakaian air bersih PDAM Way Rilau Kota Bandar Lampung baik dalam bentuk tabel, peta, maupun grafik.

- Sistem dapat menampilkan data zona pelayanan PDAM Way Rilau Kota Bandar Lampung dan kecamatan di kota Bandar Lampung dalam bentuk tabel yang dapat diubah oleh admin.

Selain kebutuhan fungsional, kebutuhan non fungsional sistem juga perlu ditentukan. Kebutuhan non fungsional mencangkup hal-hal yang dibutuhkan sistem seperti lingkungan, konten informasi, kemampuan pengguna, dan keamanan sistem. Adapun kebutuhan non fungsional dari sistem informasi geografis prediksi pemakaian air bersih ini antara lain sebagai berikut.

- Admin sistem mampu mengoperasikan Quantum GIS, Geoserver, dan Postgresql untuk menangani adanya perubahan wilayah pemetaan.

- Login disediakan untuk akses admin terhadap pengolahan data pada sistem.

- Data yang dibutuhkan antara lain: nama zona pelayanan PDAM Way Rilau Kota Bandar Lampung, kelurahan dan kecamatan di kota Bandar Lampung sebagai data master serta data pertahun yang berupa jumlah pelanggan dan jumlah pemakaian air bersih PDAM Way Rilau Kota Bandar Lampung tahun 2012-2015.

- Informasi jumlah pelanggan dan pemakaian air bersih PDAM Way Rilau Kota Bandar Lampung yang dihasilkan ditampilkan dalam bentuk peta, tabel, dan grafik.

- Perangkat lunak yang dibutuhkan antara lain Quantum GIS, Geoserver, notepad++, Chrome, dan pengolahan basis data PostgreSQL menggunakan phpPgAdmin.

\section{e. Perancangan Sistem}

Tahap ini akan menerjemahkan kebutuhan sistem ke dalam suatu perancangan atau pemodelan (software design) yang dapat diperkirakan sebelum pengkodean. Perancangan pada sistem ini terdiri atas dua bagian yaitu rancangan proses dan rancangan antarmuka. Rancangan proses pada pembangunan sistem ini menggunakan data flow diagram (DFD) dan Entity Relationship Diagram (ERD) sebagai rancangan basis data yang akan dibuat.

\section{f. Implementasi Sistem}

Implementasi dari hasil perancangan yang telah dibuat terdiri dari beberapa tahap, yaitu.

- Digitasi Peta

Digitasi peta Bandar Lampung dan peta zona pelayanan air bersih PDAM Way Rilau Kota Bandar Lampung dilakukan dengan menggunakan perangkat lunak Quantum Gis.

- Implementasi Basis Data

Basis Data yang digunakan untuk pembangunan sistem ini adalah aplikasi basis data PostgreSQL dan phpPgAdmin.

- Pembuatan Program

Sistem ini akan dibangun menggunakan bahasa pemrograman PHP dan Html.

Data yang dibutuhkan dalam sistem ini terdiri data spasial dan data non-spasial (angka data jumlah pelanggan dan pemakaian air bersih). Data spasial merupakan data hasil digitasi peta kelurahan Bandar Lampung dan peta zonasi pelayanan air bersih PDAM Way Rilau Kota Bandar Lampung menggunakan Quantum GIS yang kemudian dikonversi kedalam PostgreSQL menggunakan ekstensi PostGIS sehingga menghasilkan tipe data Geometry dan disimpan kedalam basis data.

\section{g. Pengujian}

Pengujian dilakukan setelah proses pembangunan sistem selesai. Pengujian untuk sistem ini akan dilakukan menggunakan metode pengujian fungsional sistem (Blackbox testing) dan juga menggunakan WebQual 4.0. Hasil pengujian tersebut akan dianalisis untuk mengetahui dan kemudian memperbaiki kesalahan yang mungkin terjadi saat pengujian sistem.

\section{HASIL DAN PEMBAHASAN}

Peta kelurahan Bandar Lampung dan peta zonasi pelayanan air bersih PDAM Way Rilau Kota Bandar Lampung didigitasi menggunakan Quantum GIS kemudian dikonversi kedalam data bertipe geometry dan disimpan kedalam basis data menggunakan PostGIS. Hasil konversi tersebut kemudian dikonfigurasi menggunakan Geoserver agar dapat ditampilkan pada halaman sistem. Proses konfigurasi tersebut meliputi pembuatan layer peta yang dibutuhkan sistem, penggabungan layer, penentuan warna, dan modifikasi informasi peta. Penentuan warna dilakukan berdasarkan jumlah pemakaian air bersih yang telah dibagi kedalam kelas-kelas interval menggunakan distribusi frekuensi. Terdapat dua tabel distribusi frekuensi dalam penentuan kelas interval sistem ini, yaitu tabel distribusi frekuensi untuk data pemakaian air bersih dalam wilayah zona pelayanan air bersih dan tabel distribusi frekuensi untuk data pemakaian air bersih dalam kelurahan yang berada di wilayah 
zona pelayanan PDAM Way Rilau di Bandar Lampung.

Kedua tabel distribusi frekuensi ditentukan dengan menghitung jumlah kelas yang harus dibuat dan menghitung panjang interval setiap kelas untuk membantu mendistribusikan nilai data. Berikut ini jumlah kelas untuk data pemakaian air per zona yang dihitung menggunakan rumus berikut [7].

$K=1+3,3 \log N$

Jumlah kelas yang diperoleh berdasarkan pada rumus (1) dengan jumlah data (N) 7 zona adalah sebagai berikut:

$$
\begin{aligned}
\text { Kzona } & =1+3,3 \log N \\
& =1+3,3 \log 7 \\
& =1+2,79 \\
& =3,79 \approx 4 \text { kelas }
\end{aligned}
$$

Jumlah kelas untuk data pemakaian air bersih per zona dan kelurahan dibulatkan menjadi 4 . Setelah diketahui jumlah kelas yang harus dibuat, selanjutnya menghitung interval setiap kelas menggunakan rumus berikut [7].

$$
\mathrm{C}_{\text {zona }}=\frac{\text { data terbersar }- \text { data terkecil }}{\mathrm{K}}
$$

Berikut ini adalah penentuan interval setiap kelas untuk data pemakaian air bersih per zona dengan nilai terbesar adalah $2398348 \mathrm{~m} 3$ dan nilai terkecil adalah $59256 \mathrm{~m} 3$.

$$
\begin{aligned}
& C_{\text {zona }}=\frac{2398348-59256}{4} \\
& C_{\text {zona }}=617366,31 \mathrm{~m}^{3}
\end{aligned}
$$

Distribusi frekuensi untuk data pemakaian air bersih per zona dengan jumlah 4 kelas dan interval kelas pemakaian air bersih per zona sebesar 617366 dapat dilihat pada tabel 1 .

Tabel 1Distribusi frekuensi data pemakaian air bersih per zona

\begin{tabular}{|c|c|}
\hline Kelas & Keterangan \\
\hline I & $0-617366$ \\
\hline II & $617367-1234734$ \\
\hline III & $1234735-1852101$ \\
\hline IV & $>1852102$ \\
\hline
\end{tabular}

Penentuan jumlah kelas dan interval setiap kelas untuk data pemakaian air bersih per kelurahan dilakukan dengan cara yang sama dengan penentuan jumlah kelas dan interval setiap kelas untuk data pemakaian air bersih per zona yaitu menggunakan persamaan (4) dan (5). Jumlah kelas interval untuk data pemakaian air per zona adalah sebagai berikut.

$$
\begin{aligned}
\text { Kelurahan } & =1+3,3 \log \mathrm{N} \\
& =1+3,3 \log 124 \\
& =1+6,88 \\
& =7,88 \approx 8 \text { kelas }
\end{aligned}
$$

Setelah diperoleh jumlah kelas yang dibulatkan menjadi 8 kelas, kemudian dilakukan perhitungan untuk menentukan interval kelas. Interval kelas untuk data pemakaian air bersih per kelurahan dengan nilai terbesar 230501,89 dan terkecil 874,72 adalah sebagai berikut.

$$
\begin{aligned}
& C_{\text {zona }}=\frac{230501,89-874,72}{8} \\
& C_{\text {zona }}=617366,31 \mathrm{~m}^{3}
\end{aligned}
$$

Tabel distribusi frekuensi untuk data pemakaian air bersih per kelurahan dengan jumlah 8 kelas dan interval kelas pemakaian air bersih per kelurahan sebesar 2296 dapat dilihat pada tabel 2.

Tabel 2 Distribusi frekuensi data pemakaian air bersih per kelurahan

\begin{tabular}{|c|c|}
\hline Kelas & Keterangan \\
\hline I & $0-29036$ \\
\hline II & $29037-58074$ \\
\hline III & $58075-87111$ \\
\hline IV & $87112-116148$ \\
\hline V & $116149-145185$ \\
\hline VI & $145186-174223$ \\
\hline VII & $174224-203260$ \\
\hline VIII & $>203261$ \\
\hline
\end{tabular}

Sistem informasi geografis prediksi pemakaian air bersih ini dibangun menggunakan bahasa pemrograman PHP dan HTML. Pengolahan peta dilakukan menggunakan Geoserver dan QuantumGIS untuk pembuatan peta. Penyimpanan data sistem ini menggunakan basis data PostgreSQL. Pembangunan sistem dilakukan mengacu pada DFD dan ERD yang telah dirancang sebelumnya. Halaman lihat peta pemakaian air bersih per zona dapat dilihat pada gambar 2 dan peta pemakaian air bersih per kelurahan pada gambar 3. 


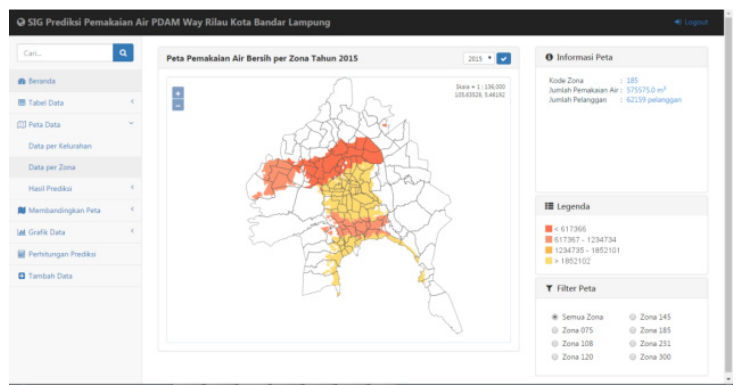

Gambar 2 Halaman lihat peta per zona

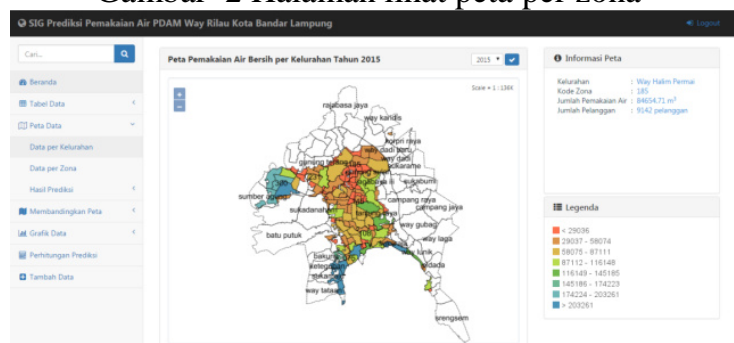

Gambar 3 Halaman lihat peta per kelurahan

Pengguna dapat melihat peta pemakaian air bersih pada tahun tertentu berdasarkan tahun yang dipilih. Prediksi jumlah penduduk dihitung dengan metode regresi linier sederhana, yaitu dengan menghitung slope (b) menggunakan persamaan 2, kemudian menghitung intercep menggunakan persamaan 3. Slope dan intercep yang didapat diigunakan pada persamaan 1 untuk menghitung jumlah pemakaian air bersih (Y).

Tahapan yang dilakukan adalah menghitung prediksi jumlah pelanggan sebagai nilai $\mathrm{Y}$ dengan tahun sebagai nilai $\mathrm{X}$ menggunakan persamaan 1 . Hasil prediksi jumlah pelanggan ini sebagai nilai $X$ pada perhitungan prediksi pemakaian air bersih sebagai nilai Y. Prediksi akan dihitung begitu proses penambahan data melalui sistem dilakukan dan prediksi akan dihitung ulang ketika terjadi perubahan pada data.

Sistem ini dapat menampilkan cara perhitungan prediksi pemakaian air menggunakaan metode regresi linier sederhana dan juga dapat menampilkan peta perbandingan jumlah pemakaian air bersih tahun asli dengan tahun prediksi. Tampilan cara perhitungan prediksi dapat dilihat pada gambar 4 dan tampilan halaman perbandingan peta dapat dilihat pada gambar 5 .

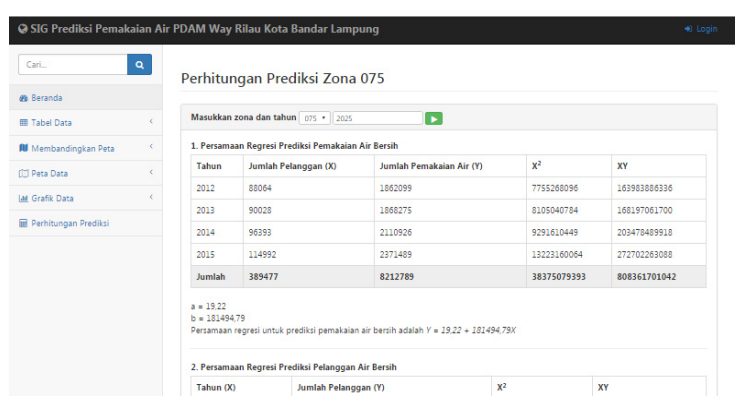

Gambar 4 Halaman perhitungan prediksi

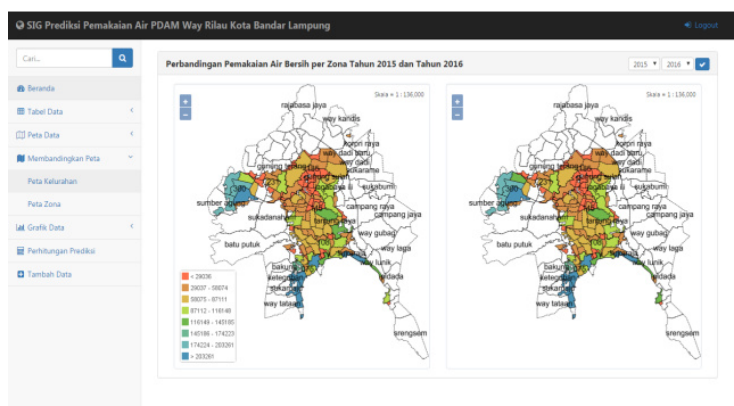

Gambar 5 Halaman perbandingan peta

Pengujian sistem dilakukan terhadap pemenuhan kebutuhan fungsional sistem dan interaksi sistem dengan pengguna. Pengujian terhadap pemenuhan kebutuhan fungsional sistem dilakukan menggunakan metode black box sedangkan pengujian terhadap interaksi sistem dengan pengguna menggunakan WEBQUAL 4. 0. Hasil pengujian terhadap pemenuhan kebutuhan fungsional sistem menunjukkan bahwa hasil telah sesuai dengan hasil yang diharapkan, sedangkan pengujian interaksi sistem dengan pengguna menggunakan WEBQUAL 4. 0 yang dilakukan oleh tiga puluh responden menunjukkan bahwa untuk kategori kegunaan (usability), jawaban setuju sebanyak $148(61,67 \%)$ dan sangat setuju sebanyak 77 (32,08\%), untuk pengujian kategori kualitas informasi, jawaban setuju sebanyak $144(68,57 \%)$ dan sangat setuju sebanyak $53(25,24 \%)$, dan untuk pengujian kategori kualitas interaksi layanan hasil yang diperoleh adalah jawaban setuju sebanyak 88 $(41,90 \%)$ dan sangat setuju sebanyak $35(16,67 \%)$.

Informasi yang tersaji dalam sistem ini dapat digunakan oleh pihak PDAM Way Rilau Kota Bandar Lampung dalam perencanaan produksi air bersih di masa mendatang. Masyarakat juga dapat mengetahui jumlah pemakaian air bersih di daerahnya baik di tahun ini maupun di masa mendatang. Informasi jumlah pemakaian air bersih disajikan dalam bentuk peta, tabel, dan grafik.

\section{KESIMPULAN}

Kesimpulan yang dapat ditarik dari penelitian ini adalah sebagai berikut.

- Hasil prediksi jumlah pemakaian air bersih PDAM Way Rilau dapat disajikan dengan sistem informasi geografis.

- Penyajian dapat dilihat berdasarkan jumlah pelanggan dalam bentuk peta, tabel, dan grafik.

- Hasil pengujian fungsional sistem menyatakan bahwa $89 \%$ dari kebutuhan pengguna terpenuhi dan $11 \%$ butuh perbaikan.

- Sedangkan hasil pengujian interaksi sistem dengan pengguna menggunakan webqual 4.0 menyatakan bahwa sistem informasi prediksi pemakaian air bersih PDAM Way Rilau Kota Bandar Lampung memiliki kualitas yang baik dari segi interaksi dengan pengguna. 


\section{DAFTAR PUSTAKA}

[1] Bangun, Sandy Setya. 2015. Evaluasi Kebutuhan Air Bersih di Kota Kabupaten Madiun sampai Tahun 2025. Tugas Akhir. Universitas Sebelas Maret.

[2] Syafruddin, M., Lukmanul Hakim, Dikpride Despa. 2013. Metode Regresi Linier untuk Prediksi KebutuhanEnergi Listrik Jangka Panjang (Studi Kasus Provinsi Lampung). Jurnal Ilmiah. Universitas Lampung.

[3] Irwansyah, Edi. 2013. Sistem Informasi Geografis: Prinsip Dasar dan Pengembangan Aplikasi. Yogyakarta: DigiBook.

[4] Smadi, Abdullah A, Nour H. Abu-Afouna. 2012. On Least Squares Estimation in a Simple Linear Regression Model with Periodically Correlated Errors: A Cautionary Note. Austrian Journal of Statistics. Vol. 41 , No. 3. ISSN: 211-226.
[5] Palacios-Marqués, Daniel, Domingo Riberio Soriano, Kun-Huang Huarng. 2015. New Information Communication Technologies for Knowledge Management in Organization. Switzerland: Springer.

[6] Futrell, Robert, Donald Shafer, Linda Shafer. 2002. Quality Software Project Management. New Jersey: Prentice Hall PTR.

[7] Supranto, J. 2000. Statistik Teori dan Analisis Edisi 6. Jakarta: Erlangga. 